JASEM ISSN 1119-8362

All rights reserved
Full-text Available Online at www.bioline.org.br/ja
J. Appl. Sci. Environ. Mgt. 2005

Vol. 9 (2) $73-79$

\title{
Growth Response of Ricinus communis L (Castor Oil) in Spent Lubricating Oil Polluted Soil
}

\author{
${ }^{*}$ VWIOKO, D E; FASHEMI, D S \\ * Department of Botany, University of Benin, Benin City, Nigeria
}

\begin{abstract}
The growth response of castor oil plant, Ricinus communis, in spent lubricating oil (SLO) was investigated using 1-6\% w/w SLO and a control. The result showed that highest percent germination of approximately 92 , was obtained in control and the least in $5 \% \mathrm{w} / \mathrm{w}$. The early germination obtained in this study was significant when considered in the light of reported delay and depression of germination by spent lubricating oil in Capsicum annum, Lycopersicon esculentum, Solanum melongena and S. incanum. For parameters like plant height, stem girth, leaf area, fresh and dry weights, and root length, the mean values obtained were higher for $1 \%$ $\mathrm{w} / \mathrm{w}$ than control. There was stimulation of growth at $1 \% \mathrm{w} / \mathrm{w}$ spent lubricating oil in soil. Plants in higher concentration $(2-6 \% \mathrm{w} / \mathrm{w})$ exhibited depression in growth. Plants grown in $1 \% \mathrm{w} / \mathrm{w}$ spent lubricating oil in soil flowered earlier than those grown in control. A difference of eight (8) days was observed. @JASEM
\end{abstract}

The disposal of spent lubricating oil into open vacant plots and farms, gutters and water drains is an environmental risk considering the water table in the South-South Region of Nigeria and shallow bore-holes dug to get water for domestic use (Odjeba and Sadiq, 2002). Anoliefo et al. (2001) studied the phytotoxic effect of soil collected from an abandoned mechanic village and reported that the soil depressed and inhibited growth of Arachis hypogaea. The suspected major soil contaminant/pollutant was spent lubricating oil from engines and other machinery. Oil in soil makes the soil condition become unsatisfactory for plant growth (De Jong, 1980), due to the reduction in the level of available plant nutrient or a rise in toxic levels of certain elements such as iron and zinc (Udo and Fayemi, 1975). There are relatively large amounts of hydrocarbons in the spent lubricating oil including the highly toxic polycyclic aromatic hydrocarbons (PAH) (Wang et al., 2000). The concentration of PAHs in lubricating oil increases with time of usage and those with two and three rings accumulate rapidly in used lubricating oil to very high levels (Boehm and Quinn, 1973). Spills arising from disposal of spent lubricating oil are becoming a visible problem especially in developing countries such as Nigeria. Therefore the usual improper disposal of used lubricating oil generated by service stations and other users now demands attention in order to protect the soil.

The castor oil plant (also known as castor bean) Ricinus communis L., is a member of the Euphorbiaceae or spurge family. It is the source of castor oil which has a wide variety of uses and ricin, a poison (Oyeleye, 2003). Castor bean is a native of tropical Africa but has naturalized in moist tropical and subtropical regions throughout the world (Anonymous, 2000). In Nigeria, apart from some parts of the middle belt notably Kogi State (where it is cultivated), castor oil plant grows in the wild and is treated as weed (Oyeleye, 2003). This underpins the use in this study. The ability of the plant to germinate and grow successfully in disturbed area was considered also. The objective of the study was to evaluate its growth in spent lubricating oil contaminated environment.

\section{MATERIALS AND METHODS}

Dried seeds of castor oil plant, Ricinus communis L., were obtained from a fallow farmland in Benin City, Nigeria. The spent lubricating oil was obtained as pooled, used engine oil from motor mechanics in different location in Benin City. The viable seeds determined by floatation were soaked in water (seed priming) for twelve hours before sowing. Primed seeds were sown in soil supplemented with water (control) and spent lubricating oil at different strengths (concentration). Soil of known weight was treated with 1, 2, 3, 4, 5 and $6 \%$ (weight of oil/weight of soil) spent lubricating oil or water before placing in polythene pots. Each treatment including the control was replicated four times. Twelve seeds were sown in each pot. The whole set up was transferred to the field. The treatments were watered every other day. The design of the experiment was completely randomised one. Oneway analysis of variance was carried out and the Least Significant Difference (LSD) test was used to compare the means. The soil used in the study was obtained from a composite sample of top soil (0 $20 \mathrm{~cm}$ ) collected around a fallow plot in the University of Benin. Teaching and Research farm 
(Lat $6^{\circ} 5^{\prime} \mathrm{N}$, Long. 55, E). The soil had been previously described by Ogunkunle (1983).

Growth parameters recorded were percent germination, plant height, leaf area, stem girth, number and length of stomata per leaf surface area, fresh and dry weight, root length and number of days to flowering. Germination was observed as the emergence of the cotyledons above the soil surface. Thinning to one plant per pot was done three weeks after planting (3WAP). Plant height was measured from the soil level to the terminal bud using a metre rule. Leaf area was determined by comparing the weight of a cut-out traced area with standard paper of known weight to area ratio (Eze, 1965) using the relationship;

$\frac{\text { Leaf Area (for } \quad \text { specimen) }}{\text { Specimen weight } \times \text { standard area }}$

Stem girth was measured by wrapping a thin thread around the stem of the plant at soil level and its length determined. Number and length of stomata per leaf surface area were determined by the impression method (Rice et al., 1979). Leaves at the third node from the apex of each plant in a pot of each treatment (including control) were harvested in the morning hours (between $8-9 \mathrm{am}$ ), abaxial surface coated with nail varnish and left to dry overnight. The dry varnish coating was peeled off carefully, placed on a slide, two drops of glycerine added and a cover slip placed over it. The preparation was viewed under the light microscope. The stomata were counted and the length of each stoma was determined using an eye piece micrometer under the objective lens x 40. Fresh and dry weights and root length of the plants were determined after flowering and seed setting. Dry weights obtained by oven drying at $80^{\circ} \mathrm{C}$ for 5 days. The number of days to flowering was counted from the date of sowing. The $\mathrm{pH}$ of soil was measured in distilled water (soil to water = $1: 3)$.

\section{RESULTS AND DISCUSSION}

Three days after planting (3 DAP) seeds sown in control and $1-3 \%$ spent lubricating oil germinated. The highest percent germination was observed in control soil (0\% SLO). Twenty-one days after planting (21 DAP) germination was observed in all concentration of spent lubricating oil contaminated soil considered in the study. The control $(0 \%)$ had the highest percent germination of 92 . This was followed by $1 \%(\mathrm{w} / \mathrm{w})$ spent lubricating oil contaminated soil. The least percent germination was observed in 5\% (w/w) spent lubricating oil contaminated soil (See Fig. 1). The difference in the treatment was found to be very significant ( $p=0.05$ ) (Fig. 1). Ricinus communis demonstrated good germinability in the SLO contaminated soil. The species germinated in all the concentration of spent lubricating oil (SLO) considered in this study $(1-6 \%)$. This capability is significant when compared to other crops like Abelmoschus esculentus (okra), Lycopersicon esculentum (tomato), Capsicum annum (pepper), Solanum melongena (eggplant) and Solanum incanum (Egg plant) which failed to germinate in concentration of SLO as high as 6\% (Anoliefo and Vwioko, 1995; Anoliefo and Edegbai, 2000). This ability is purely genetical. The plant has been reported as a pioneer species of waste land or disturbed environment (CIR, 1972). Nine days after planting (9 DAP), germination was observed in all treatments of SLO including control (see Fig. 1). Seeds germinated early. Previously, Kandambi and Dabral (1955) reported that seeds of $R$. communis germinate between 10 - 21 days after planting. Oil contaminated (polluted) soil generally causes delayed seed emergence and that of spent lubricating oil contaminated soil is not different (Anoliefo and Vwioko, 1995). This is due to poor wettability and aeration of the soil (Isirimah et al., 1989) and loss of seed viability (Rowell, 1977). Terge (1984) reported that germination of seeds in soil polluted soil varied with the different plant species. This delayed seed emergence was not noticed in this study following the emergence of seeds in 0, 1, 2 and 3 \% SLO treated soil 3 DAP. This barrier to early seed emergence in polluted soil may have been minimized (if not eliminated) by the soaking of the $R$. communis seeds in distilled water 12 hours before planting. Seed priming advances germination by inducing a wide range of biochemical changes in the seed (DFID, 2002). The result observed in germination suggests that delayed seed germination in oil contaminated soil can be eliminated by soaking in water before planting. This is significant in an attempt to revegetate an oil-impacted environment and $R$. communis is a good species for such. This has in no means removed the fact that spent lubricating oil in soil depressed percent germination obtained 21 DAP as SLO concentration in soil increases. The reduction in percent seed germination 21 DAP observed can be attributed to absorption of the applied oil by the soil which came in contact with the castor oil seeds and penetrated their embryo. Udo and Fayemi (1975) and Amadi et al. (1993) observed that increasing the concentration of oil 
beyond $3 \%$ in soil reduced percentage germination by the coating of oil on seed surface, thereby

affecting physiological functions within the seed.

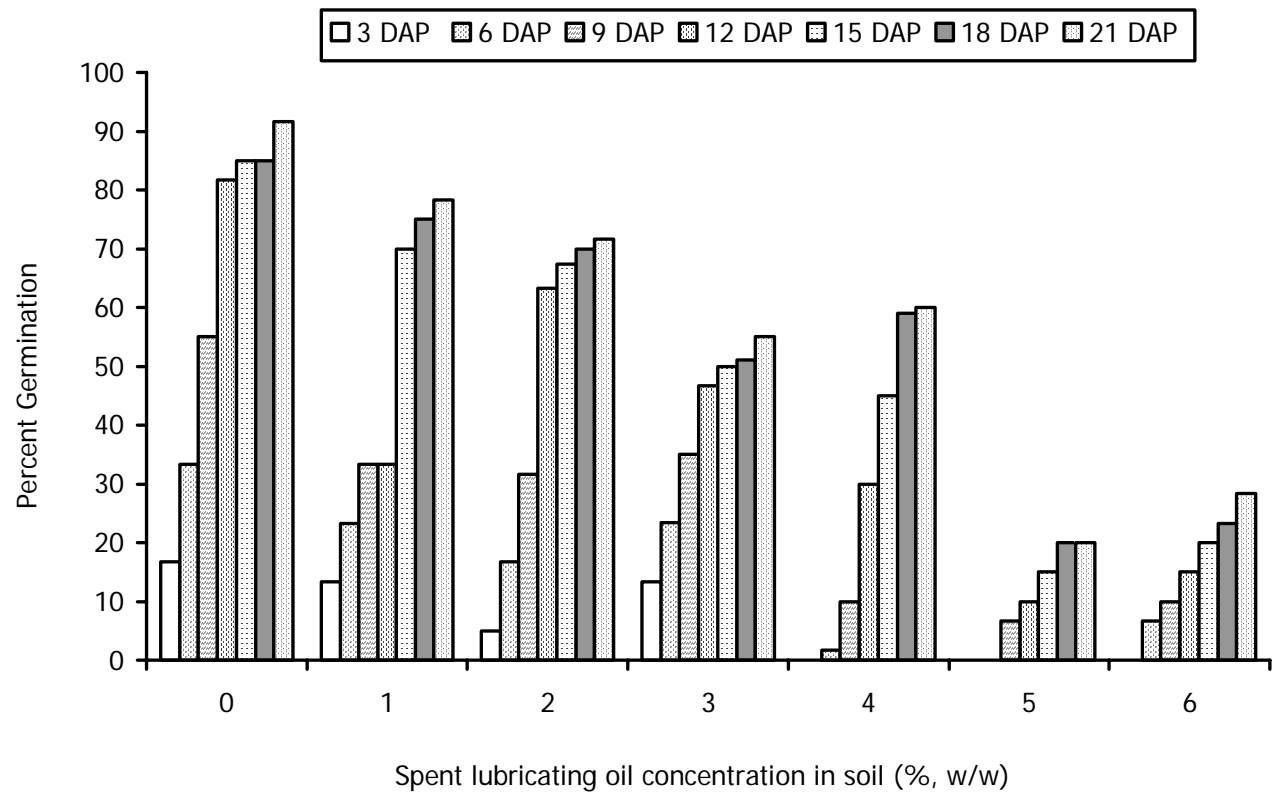

Fig. 1. Percent germination of seeds of Ricinus communis (castor oil) sown in different concentration of spent lubricating oil contaminated soil.

The mean plant height obtained is shown in Fig. 2 below. The highest value was obtained for plants grown in $1 \%$ spent lubricating oil contaminated soil. The least values were obtained for plants grown in $4 \%$ spent lubricating oil contaminated soil 91 DAP. The difference in treatment was also observed to be significant $(\mathrm{P}=0.05)$. The LSD test showed that the response of the plant in terms of height with respect to concentration (\%) of the contaminant in soil can be gradated in this order as $1>0>2>3>5>6>4$. The spent lubricating oil in soil at concentration greater than $2 \%(\mathrm{w} / \mathrm{w})$ decreased mean leaf area (See Table 1 below). Mean values of $633.00 \mathrm{~cm}^{2}$ and82.19 $\mathrm{cm}^{2}$ were obtained for $1 \%$ and $0 \%$ (control) respectively, 70 DAP. The mean value obtained for $2 \%(\mathrm{w} / \mathrm{w})$, $83.83 \mathrm{~cm}^{2}$, was higher than that for control (82.19 $\left.\mathrm{cm}^{2}\right)$.

Table 1: Leaf area $\left(\mathrm{cm}^{2}\right)$ of Ricinus communis (castor oil) plants grown in spent lubricating oil contaminated soil.

\begin{tabular}{ccc}
\hline \multirow{2}{*}{ Oil concentration } & \multicolumn{2}{c}{ *Days after planting (DAP) } \\
\cline { 2 - 3 } & 49 & 70 \\
\hline 0 & $47.61 \pm 28.27$ & $82.19 \pm 36.60$ \\
1 & $126.25 \pm 62.62$ & $633.00 \pm 110.95$ \\
2 & $70.08 \pm 32.20$ & $83.83 \pm 33.93$ \\
3 & $85.06 \pm 36.68$ & $93.20 \pm 2.76$ \\
4 & $12.30 \pm 0.93$ & $15.71 \pm 2.23$ \\
5 & $14.44 \pm 2.27$ & $22.83 \pm 5.44$ \\
6 & $16.91 \pm 2.45$ & $24.12 \pm 5.44$ \\
\hline$*=$
\end{tabular}

$*=$ mean \pm S.D.
The least value obtained was for $4 \% \mathrm{w} / \mathrm{w}$ concentration. Figure 3 shows the stem girth of Ricinus commnnis plants grown in spent lubricating oil contaminated soil 83 DAP (Fig. 3). The highest values were obtained in $1 \%(\mathrm{w} / \mathrm{w})$ SLO and $0 \%$ (control). Least values were obtained in 3 and $4 \%(w / w)$ SLO. The differences in treatments and control was found to be significant. No difference was found between 1\% SLO and 0\% (control). The data obtained for plant height, stem girth and leaf area showed significant differences between the control, 1\% SLO treatment and $2-6 \%$ SLO treatment. At $1 \%$ SLO treatment, the mean plant height, stem girth and leaf area obtained were higher than control about 11, 3 and $670 \%$ respectively. Suggesting a growth stimulating effect at this concentration of SLO. A similar effect was observed for Solanum melogena at $1 \%$ SLO concentration in soil by Anoliefo and Edegbai (2000). This effect was not observed for other plant species like Capsicum annum, Solanum lycopersicon, Abelmosclus esculentum and Solanum incanum. For Ricinus communis plants grown in $2-6 \%$ SLO in soil showed depression in height, stem girth and leaf area. The $2-6 \%$ SLO in soil resulted in greater changes in soil condition which imposed stressful conditions that interfered with water uptake and gaseous exchange. This may have created a conditions of physiological drought McCown et al. (1972) stated that the disruption of 
soil physical properties by crude oil with anaerobic and hydrophobic condition was found largely responsible for reduction in plant growth. There may also be accompanying stomatal closure and a decrease in leaf, stem and root dry weights in poorly aerated soils (Smith et al., 1989). Table 2 shows that values obtained for number and length of stomata of leaves. The $1 \%$ SLO treatment gave the highest number of stomata but their sizes were less than that observed in control. The distinction between the stomata of leaves of treated and control plants were conspicuous. Dark glossy spots were observed in the stomata inner linings of leaves obtained from treated plants. These dark glossy spots were oil droplets taken up by the treated plants which could not evaporate into the atmosphere. The SLO treatment affected the length of stomata.

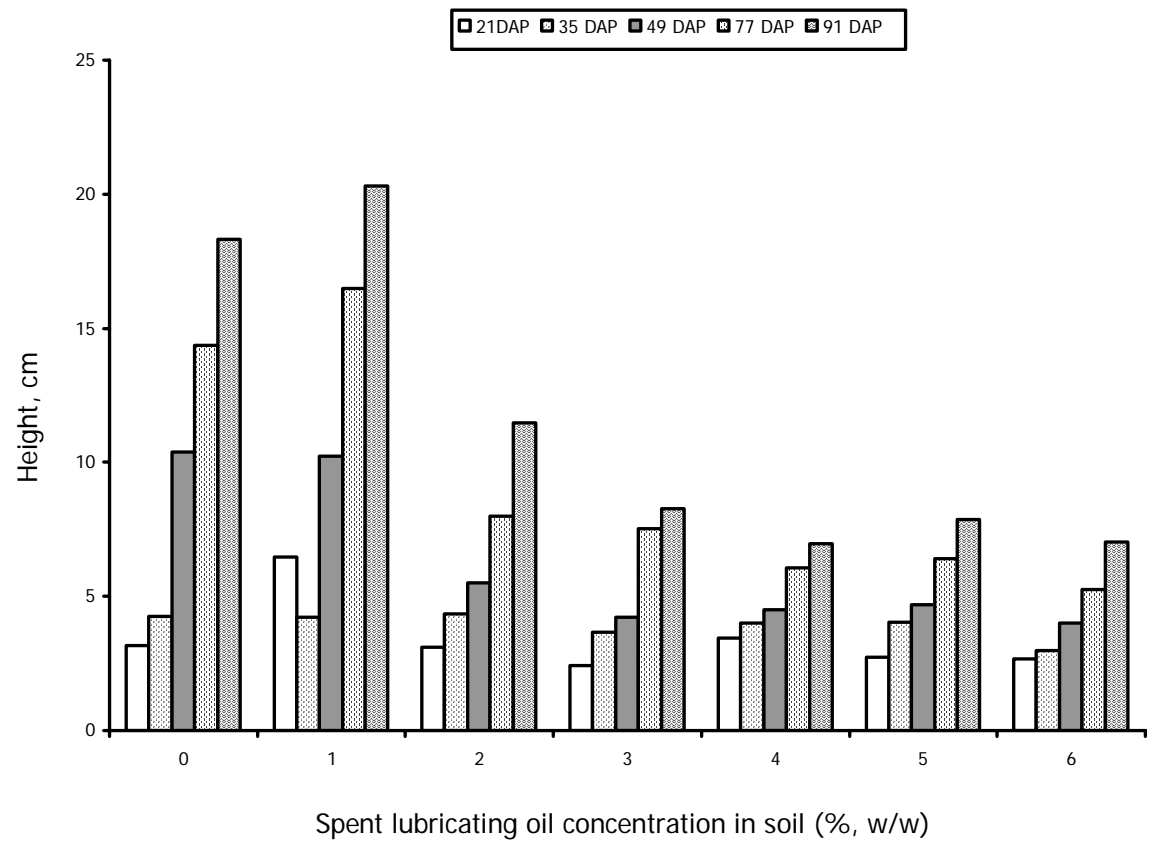

Fig. 2. Mean height (cm) of Ricinus communis (castor oil) plants grown in spent lubricating oil contaminated soil.

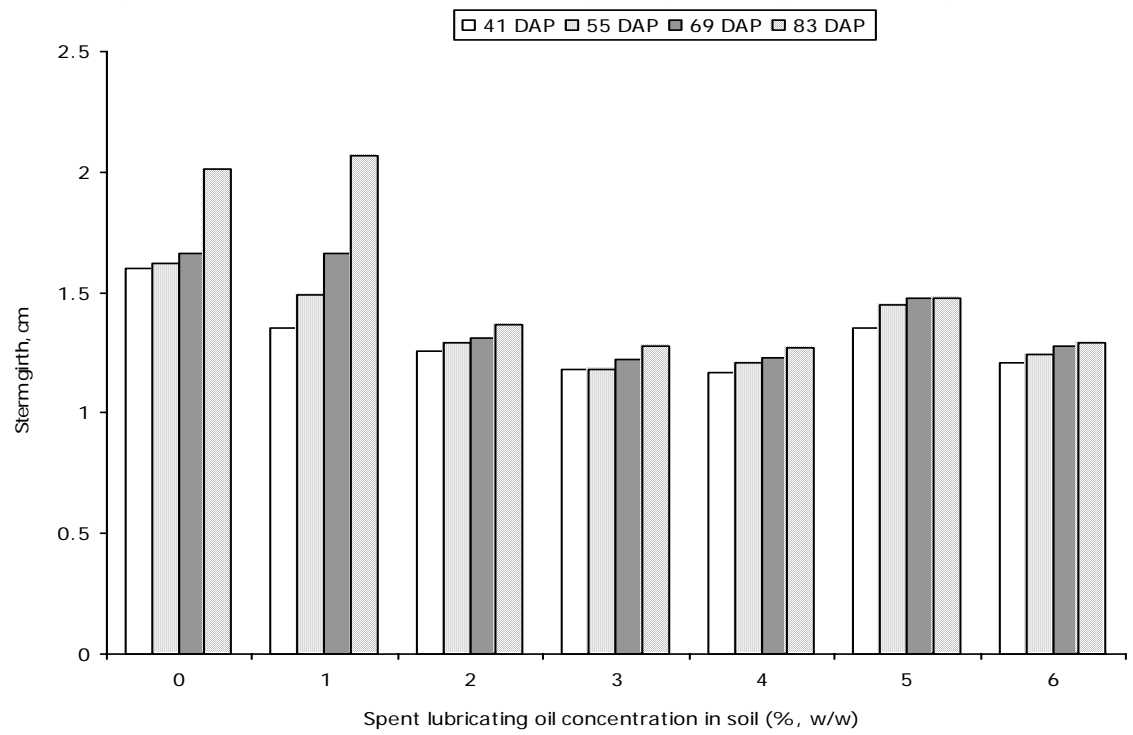

Fig. 3. Stem girth (cm) of Ricinus communis (castor oil) plants grown in spent lubricating oil contaminated soil 
Table 2: Number and mean length $(\mathrm{cm})$ of stomata per surface area of leaves of Ricinus communis grown in spent lubricating oil contaminated soil. * = mean \pm S.D.

\begin{tabular}{ccc}
\hline Oil concentration & Mean number of stomata & $\begin{array}{c}* \text { Mean length (PIM) of stomata } \\
(\text { mean } \pm \text { S.D) }\end{array}$ \\
\hline 0 & 26 & $0.029 \pm 0.0054$ \\
1 & 32 & $0.025 \pm 0.0022$ \\
2 & 26 & $0.025 \pm 0.0022$ \\
3 & 28 & $0.023 \pm 0.0031$ \\
4 & 28 & $0.023 \pm 0.0031$ \\
5 & 21 & $0.016 \pm 0.0085$ \\
6 & 19 & $0.025 \pm 0.0022$ \\
\hline
\end{tabular}

The values obtained for treated plants were lower than that of control. Plants are known to close their stomata in response to water stress, thus limiting water loss. Stomata play a pivotal role in controlling the balance between water loss and biomass production. Measurement of the size of the stomatal opening (stomatal aperture) or of the resistance to $\mathrm{CO}_{2}$ and water vapour $\left(\mathrm{H}_{2} \mathrm{O}\right)$ transfer between the atmosphere and the internal tissues of the leaf imposed by the stomata (stomatal resistance) are important in many studies of biomass production (Rice et al., 1979). In plant growing under stress conditions, changes in stomata size are mostly observed in the length and not width. In this study the distinction between the stomata of control plants and treated was very glaring. Larger and very conspicuous outlined stomata were observed in the control as compared to treated plants. The number of stomata observed was higher for $1 \%$ SLO than control. In terms of size, $1 \%$ SLO treated plants have smaller stomata than control (see Table 2). The number of stomata per leaf surface area should suggest the photosynthetic rate of that plant. However, the rate of $\mathrm{CO}_{2}$ movement into the leaf depends, among others, upon the number of stomata present per unit area of leaf (Causton and Venus, 1981). Increased rate of $\mathrm{CO}_{2}$ increases rate of photosynthesis. The spent lubricating oil treatment reduced the length of stomata in $R$. communis. The adverse effects of environmental pollution on plant growth range from morphological aberrations, reduction in biomass to stomatal abnormalities (Sharma et al., 1980). Gill et al. (1992) reported that stomata in Chromolaena odorata were grossly affected by crude oil which manifested as distortion and reduction in the number of stomata per unit area of the leaf. In this study $2-6 \%$ SLO concentration in soil reduced fresh and dry weights and root length. The ranges of reduction were: fresh weight 9 $88 \%$, dry weight $27-87 \%$ and root length $32-$ $60 \%$ (see Table 3). This indicates that the SLO treatment affected dry matter accumulation in $R$. communis. Table 3 shows the fresh weight, dry weight and root length $(\mathrm{cm})$.

Table 3: Fresh weight (g), dry weight (g) and mean root length (cm) of Ricinus communis grown in spent lubricating oil contaminated soil.

\begin{tabular}{cccc}
\hline Oil concentration & Fresh weight $(\mathrm{g})$ & Dry weight $(\mathrm{g})$ & Mean root length $(\mathrm{cm})$ \\
\hline 0 & $155.00 \pm 12.73$ & $67.00 \pm 2.64$ & $52.70 \pm 2.40$ \\
1 & $647.70 \pm 28.23$ & $312.50 \pm 25.17$ & $106.2 \pm 26.53$ \\
2 & $141.05 \pm 6.44$ & $49.09 \pm 1.29$ & $31.25 \pm 0.35$ \\
3 & $77.50 \pm 8.44$ & $25.11 \pm 4.39$ & $36.00 \pm 6.27$ \\
4 & $45.95 \pm 6.15$ & $17.37 \pm 4.31$ & $20.00 \pm 3.54$ \\
5 & $36.50 \pm 9.19$ & $8.64 \pm 0.95$ & $28.85 \pm 7.71$ \\
6 & $18.35 \pm 2.33$ & $9.05 \pm 1.18$ & $20.65 \pm 8.70$ \\
\hline
\end{tabular}

Figures are mean \pm S.D.

Table 4: Mean number of days to flowering of Ricinus communis (castor oil) plants grown in spent lubricating oil contaminated soil

\begin{tabular}{cc}
\hline Oil concentration (\%) & Number of days to flowering after planting \\
\hline 0 & 96 \\
1 & 88 \\
2 & - \\
3 & - \\
4 & - \\
5 & - \\
6 & - \\
\hline
\end{tabular}


The plants in $1 \%$ SLO treated soil produced flowers earlier than the control $(0 \%)$. The treated plants flowered 88 DAP while control flowered 96 DAP, a difference of 8 days. Table 4 shows the numbers of days to flowering. The plants in $2 \%$ SLO and higher failed to flower before the termination of the study. The results of our study showed that the $1 \%$ SLO treated plants flowered earlier than the control - a difference of about 8 days was recorded. For concentration higher than $1 \%$ SLO, the plants failed to flower before the termination of the experiment. The early flowering in 1\% SLO in soil is not unconnected with the growth enhancement and early maturity observed. We are of the view that spent lubricating oil at low concentration has proven to be beneficial to $R$. communis. This is because oil pollution up to $1 \%$ could easily be degraded by natural rehabilitation in soils, increase organic matter in soil and improve the fertility, physical and chemical properties of the soil (Anoliefo and Edegbai, 2000). The early flowering observed in this study following the $1 \%$ SLO concentration in soil may have physiological and genetical dimensions. The increasing acidic condition of the soil following increased SLO concentration increases the availability of heavy metals to plants. This suggests an explanation for the poor plant growth obtained in SLO concentration greater than $3 \%$. Table 5 shows the mean $\mathrm{pH}$ values obtained. $\mathrm{pH}$ values decreased as the concentration of SLO increased.

Table 5: Mean $\mathrm{pH}$ values of spent lubricating oil contaminated soil before planting Ricinus communis (castor oil) seeds

\begin{tabular}{cc}
\hline Oil concentration (\%) in soil & Mean $\mathrm{pH}$ values \\
\hline 0 & 5.28 \\
1 & 5.09 \\
2 & 4.96 \\
3 & 5.04 \\
4 & 4.90 \\
5 & 4.83 \\
6 & 4.82 \\
\hline Measurement was done using distilled water
\end{tabular}

(soil: water $=1: 3$ )

There is need for further studies on metal accumulating ability of $R$. communis. It may be necessary to evaluate the performance of $R$. communis in revegetation of cleaned up oil polluted soils. More importantly, we need to look at the production of growth hormones in $R$. communis plants grown at $1 \%$ SLO.

\section{REFERENCES}

Anoliefo,G O; Edegbai,B O (2000). Effect of spent engine oil as a soil contaminant on the growth of two egg plant species, Solanum melongena L. and Solanum incanum L. Journal of Agriculture, Forestry and Fisheries, 1: 21 - 25.
Anoliefo,G O; Isikhuemhen,O S; Agbuna,S O (2001). Small-scale industrial village in Benin City, Nigeria: Establishment, failure and phytotoxicity assessment of soils from the abandoned site. Water, Air and Soil Pollution 131: $169-183$.

Anoliefo,G O; Vwioko,D E; Mpamah,P (2003). Regeneration of Chromolaena odorata (L.) K. \& R. In crude oil polluted soil: A possible phytoremediating agent. Benin Science Digest 1: $9-14$.

Anoliefo,G O; Vwioko, D E (1995). Effects of spent lubricating oil on the growth of Capsicum annum L. and Lycopersicon esculentum Miller. Environmental Pollution 88: 361 - 364.

Anoliefo,G O; Vwioko,D E (2001). Tolerance of Chromolaena odorata (L) K. \& R. grown in soil contaminated with spent lubricating oil. Journal of Tropical Bioscience 1: 20 - 24.

Anonymous (2000). Castorbean, castor oil plant. www.vet.purdue.edu/depts/add /toxic/plantII.htm.

Boehm,P D; Quinn,J G (1973). Solubilisation of hydrocarbons by dissolved organic matter in seawater. Geochimica et Cosmochin Acta 37: $2459-2477$.

Causton,D R; Venus,J C (1981). The biometry of plant growth. Edward Arnold Pub. Ltd., London, 307p.

CSIR (1972). The wealth of India. Raw materials. Vol. 9. Publications and Information Directorate, Council for Scientific and Industrial Research, New Delhi, 472p.

De Jong, E (1980). The effect of a crude oil spill on cereals. Environmental Pollution, 22: 187 196.

DFID (2002). On-farm seed priming, a key technology to improve the livelihoods of resource-poor farmers in India. Department for International Development, Plant Sciences Research Programme and KRIBHCO. Indo British Rainfed Farming Project, India. 6p.

Eze, J M O (1965). Studies on growth regulation, salt uptake and translocation. Ph. D. thesis, University of Durham, UK. pp. 31 - 33. 
Gill, L S; Nyawuame, H G K ; Ehikhametalor,A O (1992). Effect of crude oil on the growth and anatomical features of Chromolaena odorata (L) K. \& R. Chromolaena odorata Newsletter No. 6: $1-6$.

Isirimah, $\mathrm{N} \quad \mathrm{O}$; Zoufa,K ;Loganathan,P (1989). Effect of crude oil on maize performance and soil chemical properties in the humid forest zone of Nigeria. Discovery and Innovation , 1: $95-98$.

Kandambi, K ; Dabral,S N (1955). The silviculture of Ricinus communis Linn. Indian Forester, 81(1): $53-58$.

McCown, B H ; Deneke, F J; Richard, W E ; Tieszen, L I (1972). The response of Alaskan terrestrial plant communities to the presence of petroleum. In: Proceedings of the symposium on the impact of Oil Research Development on Northern Plant Communities, 23rd AAAS Alaskan Science Conference, Fairbanks, Alaska, 17 August 1972. Occas. Publ. North Life No. 1, pp. $34-43$.

Odjeba, V J; Sadiq, A O (2002). Effects of spent engine oil on the growth parameters, chlorophyll and protein levels of Amaranthus hybridus L. The Environmentalist 22: 23 - 28.

Ogunkunle, S (1983). NIFOR Soil Report. Journal of the Nigerian Institute for Oil Palm Research 6(23): $234-255$.

Oyeleye, O (2003). Castor plant, benefits waiting to be tapped. The Guardian, Sunday November 23, 2003. vol. 20. No. 9, 133. Jahman Oladejo
Anikulapo (editor). Published by Guardian Newspapers Ltd., Rutam House, Isolo, Lagos, Nigeria. p. 24.

Rice, J S; Glenn, E M ; Quisenberry, V L (1979). A rapid method for obtaining leaf impressions in grasses. Agronomy Journal. 71: 894 - 896.

Rowell, M J (1977). The effect of crude oil spills on soils. In: The reclamation of agricultural soils after oil spills, J.A. Toogood (editor). Department of Soil Science, University of Alberta, Edmonton. pp. 1 - 33.

Sharma, G K; Chandler,C ; Salemi,L (1980). Environmental pollution and leaf cuticular variation in Kadzu (Puereria lobata Willd). Annals of Botany, 45: $77-80$.

Smith, B; Stachowisk,M ;Volkenburgh, E (1989). Cellular processes limiting leaf growth in plants under hypoxic root stress. Journal of Experimental Botany 40: 89 - 94.

Terge, K (1984). Effect of oil pollution in the germination and vegetative growth of five species of vascular plants. Oil and Petroleum Journal 2: 25 - 30.

Udo, E J; Fayemi,A A A (1975). The effect of oil pollution on soil germination, growth and nutrient uptake of corn. Journal of Environmental Quality 4: 537 - 540.

Wang, J; Jia,C R; Wong,C K ; Wong,P K. (2000). Characterization of polycyclic aromatic hydrocarbons created in lubricating oils. Water, Air and Soil Pollution, 120: 381 - 396. 